\title{
Evaluation of pumpkin-rowanberry marmalade quality after different drying times
}

\author{
E. Berna, S. Kampuse, M. Sabovics, E. Straumite \\ Faculty of Food Technology, Latvia University of Agriculture, \\ Liela Str. 2, LV-3001 Jelgava, Latvia; \\ E-mail: elga@tvnet.lv
}

cross'ref http://dx.doi.org/10.5755/j01.ct.62.4.3412

Received 30 December 2012; Accepted 7 January 2013

Historically, marmalades may have originated as an early effort to preserve fruit for consumption in the off-season. Marmalades are basically products with fruit purée and sugar-acid-pectin gel. The aim of the current research was to determine the chemical and physical properties and to investigate the degree of acceptance of pumpkin-rowanberry marmalade.

The experiments were carried out at the Faculty of Food Technology of the Latvia University of Agriculture. The marmalade was made from Cucurbita maxima pumpkin and sweet rowanberry Sorbus aucuparia cultivar 'Nevezhinskaya' purées. Different drying times in oven at a temperature of $50 \pm 2{ }^{\circ} \mathrm{C}$ were examined and compared with marmalade drying in air ambiance at room temperature. The moisture, total carotene, ascorbic acid content, hardness, colour, and the degree of acceptance of marmalade samples were determined as quality evaluation.

The results of the research have shown a large variability in the physical and chemical parameters among the marmalades after different drying times. The moisture content of marmalade samples decreased by 9.1 to $33.5 \%$, and hardness increased from 1.85 to $9.54 \mathrm{~N}$. According to sensory evaluation, consumers liked pumpkin-rowanberry marmalade samples after drying in the air ambiance at room temperature.

Keywords: marmalade, total carotene content, hardness, colour, degree of acceptance

\section{Introduction}

Sweets constitute a group of food for which human beings have always had some inborn preference because the majority of sweet fruits or edible parts of plants found in nature are not poisonous. The group of sweets includes honey, candies, jellies and marmalades, candied fruits, sweets made of cacao, and others [1]. Historically, marmalades, jams and jellies may have originated as an early effort to preserve fruit for consumption in the offseason. The processing of different fruits into juice, marmalade or jam has been important for ensuring fruit availability all the year round. Marmalades are mostly products from fruit purée and sugar-acid-pectin gel or low-methoxyl pectin-calcium gels. Pectin is traditionally used in a wide range of fruit-based products in which it acts as a gelling agent [2-4]. For the production of marmalade, fresh fruits or intermediary products, such as fruit pulps or slurries, are boiled with the addition of sugar and other ingredients (gelling agents, starch syrup, and acids) [5].

Berries are among the most suitable fruits for processing into jams and jellies because of their quality, acidity, colour, high pectin content, flavour, and aroma. If a fruit does not have enough pectin, commercial pectin has to be used, when a mixture of the required pectin with a similar portion of sugar should be added after the concentration process to avoid heat damage to the pectin molecules. Sugar and other minor ingredients help to develop the texture of jams and marmalades because of the formation of a gel between sugars and pectin substances along with fruit acidity $[2,3]$.
Consumers demand high-quality healthy products in various innovative forms and for competitive prices [5]. Therefore, it is very important to choose the raw material with a high content of bioactive compounds. There is still a lot of potential to improve the product quality using new, non-traditional fruits and vegetables as raw materials for the production of marmalades. Such raw materials are also pumpkins and sweet rowanberries.

Pumpkin is one of the vegetables that meet the requirements of healthy nutrition; it is a gourd-like squash of the genus Cucurbita and the family Cucurbitaceae. It is a tasty and valuable vegetable crop containing a lot of biologically active substances and distinguished for dietary qualities. The name 'pumpkin' is commonly used for cucurbits of some species similar in botanical characteristics. In Central Europe an countries, pumpkins belonging to Cucurbita pepo L. (called also 'squash'), Cucurbita maxima Duch. (called 'winter squash') and Cucurbita moschata Duch. ex Poir species are mostly grown. Since pumpkin species and cultivars differ in the nutritional and technological value of fruits, breeders and scientists seek genotypes of the highest nutritional value and suitability for human nutrition $[6,7]$.

The yellow-orange characteristic colour of pumpkin is due to the presence of carotenoids which have a major role in nutrition as provitamin $\mathrm{A}$ and as an antioxidant [8]. The main carotenoids present in winter squash (Cucurbita maxima) are $\alpha$-carotene and $\beta$-carotene. Winter squash fruit contains $0.4-7.5 \mathrm{mg} 100 \mathrm{~g}^{-1}$ of $\alpha$-carotene and 1.4-

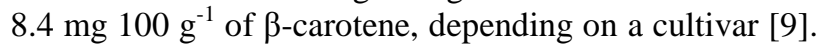
Cucurbita moschata is used in the traditional medicine of 
several countries to control diabetes as well as for treating worms and parasites [10]. They are consumed in various ways such as fresh or cooked; also they are stored frozen or canned [11].

The rowanberries Sorbus belong to the subfamily Maloideae of the family Rosaceae, and their berries have been promoted as a health-food or a source of healthpromoting components. Wild rowanberries have been traditionally used to make purées, juices or wine, and they make an excellent jelly because of the high content of pectin, but their wider use as food ingredients has been less popular because of their bitter taste. Sweeter and less astringent than wild rowanberries are different cultivars of sweet rowanberries and hybrids with other species. The first sweet rowanberry clones were selected in the Sudety mountain area, in the current Czech Republic area in the 19th century. A breeding program for sweet rowanberries was started by Michurin in Russia at the beginning of the 20th century, resulting in interesting hybrids of the rowanberry (Sorbus aucuparia L.) with the Aronia, Malus, Mespilus, or Pyrus species. Sweet rowanberries have been bred particularly for northern conditions and have shown excellent winter-hardiness in Russia and Finland [12, 13]. According to food composition and nutrition tables, sweet rowanberry S. aucuparia L. var. edulis contains 1600-2420 mg of organic acids per $100 \mathrm{~g}$ of edible portion, $98 \mathrm{mg}$ of vitamin $\mathrm{C}$ per $100 \mathrm{~g}$, and $2.5 \mathrm{mg}$ of total carotenoids per $100 \mathrm{~g} \mathrm{[14]}$. A comparison of data on sugar content in wild rowanberries indicated that cultivars of the sweet rowanberries were sweeter - sugar content in their fruits was considerably (1.2-2.1 times) higher [15].

The stability of many bioactive compounds is dependent on the pre-treatment of the raw material, processing operations of the product, and storage conditions. In many fruits, carotenoids and flavonoids, located mainly in epidermal tissues, are removed by peeling operations which can greatly reduce the concentrations of bioactive compounds in processed products. Removal of seeds can result in a loss of phenolics (e. g., ellagitannins) [16]. Drying in the hot air is mostly performed at a temperature ranging between 50 and $90{ }^{\circ} \mathrm{C}$; it must be chosen very carefully for drying fruits and berries. These reactions cause not only browning and the loss of pigments [17], but also the loss of important nutrients. High temperature causes the loss of important nutrients, non-enzymatic browning, some enzymatic and other reactions [18]. At a temperature just above $50{ }^{\circ} \mathrm{C}$, the degradation of several phenolic compounds occurs [19], but at $60-63{ }^{\circ} \mathrm{C}$ anthocyanin degradation begins [20]. During the thermal processing, 50-70\% losses of ascorbic acid can occur. The losses of this vitamin are used as an indicator of food quality. On the other hand, carotenoids after thermal processing are more easily extracted from plant tissues due to tissue softening and the destruction of the membrane-protein complex [16].

Colour and texture are very important quality parameters of marmalades. The colour is one of the most important parameters to which consumers are sensitive when selecting foods. Colour stability of fruit and fruit products is influenced by many factors. At least three factors can cause colour deterioration: the loss of red anthocyanin pigment, formation of brown pigments, and discoloration through various factors such as heavy metal contaminations. The fruit cultivar, temperature, $\mathrm{pH}$, presence of oxygen and the time of processing were found to exert a great influence on colour stability of fruit products $[21,22]$

The aim of the current research was to determine the chemical and physical properties and to investigate the degree of acceptance of pumpkin-rowanberry marmalade after different times of drying at a temperature of $50 \pm 2{ }^{\circ} \mathrm{C}$.

\section{Materials and methods}

The object of the research was pumpkin-rowanberry marmalade. The principal technological scheme of its preparation and drying is shown in Fig. 1. The pumpkin Cucurbita maxima and sweet rowanberry Sorbus aucuparia cultivar 'Nevezhinskaya' purées were the main raw material for the preparation of the marmalade. The rowanberry purée was made from frozen and defrosted rowanberries.

The dimensions of one piece of pumpkin-rowanberry marmalade was $90 \mathrm{~mm} \times 70 \mathrm{~mm} \times 20 \mathrm{~mm}$ and the mass $100 \pm 5 \mathrm{~g}$. Part of marmalade samples were dried at room temperature, i. e. $22 \pm 2{ }^{\circ} \mathrm{C}$, for $24 \mathrm{~h}$ as a control sample, and other samples were dried in convection oven HS 30 with air ventilation at a temperature of $50 \pm 2{ }^{\circ} \mathrm{C}$ for 24 , 48 and $56 \mathrm{~h}$. Chemical (moisture, total carotene and ascorbic acid content), physical (hardness, colour L*a*b* values) and sensory analyses of the marmalade samples were carried out.

Moisture content was analyzed by the gravimetrical method at a temperature of $97 \pm 1{ }^{\circ} \mathrm{C}$ [23] using an oven TR60 (Naberthern) and analytical scales BP-210s (Sartorius) in three replications. The total carotene content was analysed by the spectrophotometric method at $440 \mathrm{~nm}$ [24] with petroleum ether (boiling temperature range $80-110^{\circ} \mathrm{C}$ ) and measured with a UV-VIS-NIR spectrophotometer UV-3100PC (Shimadzu) in $10 \mathrm{~mm}$ cuvettes. A total of 2-3 grams of homogenized marmalade was placed in a conic retort $(100 \mathrm{ml})$ and $96 \%$ ethanol $(20 \mathrm{ml})$ was added, and then samples were stirred with a magnetic stirrer for $20 \mathrm{~min}$. Then petroleum ether $(25 \mathrm{ml})$ and water $(1 \mathrm{ml})$ were added, and stirring was continued for one more hour. After 3-4 hours, the top (yellow) layer was used for the detection of total carotenoids. The carotene equivalent $(\mathrm{KE})$ was found using the graduating curve with $\mathrm{K}_{2} \mathrm{Cr}_{2} \mathrm{O}_{7}$. The measurements were carried out in two replications for each sample.

The hardness (cutting force in N) of marmalades was determined with a Texture Analyser TA.XT.plus (Stable Micro Systems Ltd., Surrey, UK) and the measuring probe A/BC (butter cutter, can be used for soft samples; it is supplied together with the Texture Analyser) [25]. The maximum force required for sample compression was calculated as an average of 10 measurements.

The colour of marmalades was measured in the CIE $\mathrm{L}^{*} \mathrm{a} * \mathrm{~b} *$ colour system using a ColorTec-PCM/PSM 
(Accuracy Microsensors Inc., USA). Ten random areas were measured, and the mean values were reported for each sample. In colour measurement, CIELAB coordinates show the degree of brightness (L), the degree of redness $(+a)$ or greenness $(-a)$, and the degree of yellowness $(+b)$ or blueness $(-b)$, respectively [26, 27].

In order to assess the consumer's acceptability of pumpkin-rowanberry marmalade hardness, the ranking test (ISO 8587:2006 Sensory analysis - Methodology Ranking) was used. The sensory analysis of pumpkinrowanberry marmalade was performed at the $16^{\text {th }}$ International Exhibition 'Riga Food 2011'. In the evaluation, 61 consumers (48 females and 13 males) took part; their mean age was 32 years.

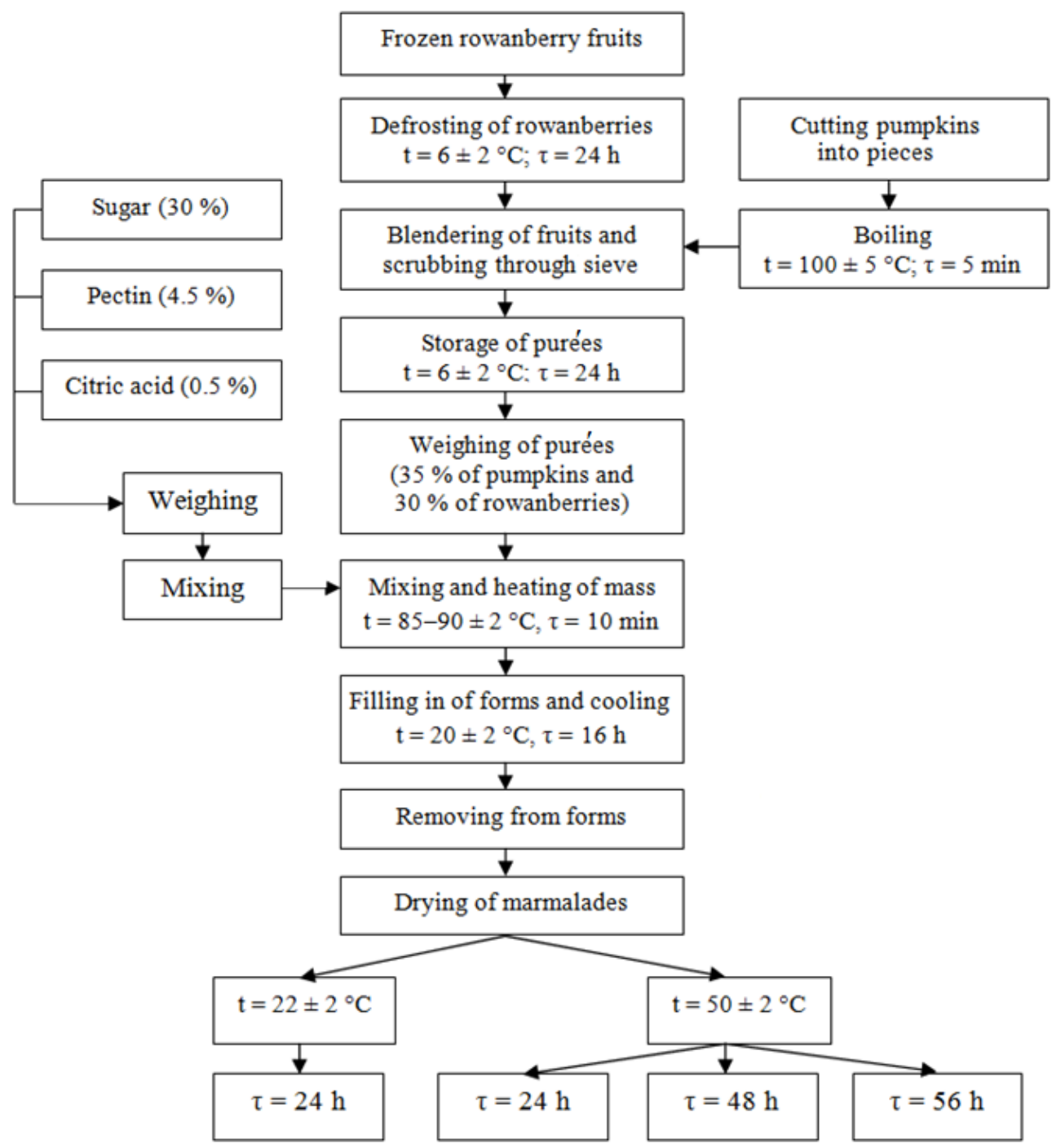

Fig. 1. The principal technological scheme of pumpkin-rowanberry marmalade preparation and drying

The results were processed by mathematical and statistical methods. The data were analysed using the statistical analysis of variance (ANOVA) and the Friedman test; significance was defined at $p<0.05$.

\section{Results and discussion}

The chemical and physical parameters of the pumpkin-rowanberry marmalades dried at a temperature of $50 \pm 2{ }^{\circ} \mathrm{C}$ for 24,48 and $56 \mathrm{~h}$ and the values of control samples (marmalade dried at room temperature for $24 \mathrm{~h}-$ further in the text designated as marmalade samples dried at $50 \pm 2{ }^{\circ} \mathrm{C}$ for $0 \mathrm{~h}$ ) are given in Table 1 .

The moisture content of pumpkin-rowanberry marmalade samples was found to have decreased by $7 \%$,
$22 \%$ and $26 \%$ according to the drying time of samples, and there was a significant difference $(p=0.000)$ in the moisture content among the samples.

The total carotene content of pumpkin-rowanberry marmalade after drying at room temperature for $24 \mathrm{~h}$ was $3.31 \pm 0.16 \mathrm{mg} 100 \mathrm{~g}^{-1} \mathrm{DW}$ (see Table 1). After 24 hours of marmalade drying at $50 \pm 2{ }^{\circ} \mathrm{C}$, the total carotene content decreased by $14.6 \%$, but after the further drying there were no significant $(p=0.06)$ changes. Therefore, we can conclude that drying the samples at $50 \pm 2{ }^{\circ} \mathrm{C}$ causes a fast decrease of carotenes content as soon as after 24 hours, but the further drying at the same temperature does not decrease the content of these pigments. 
Table 1. Changes of pumpkin-rowanberry marmalade quality parameters during the drying of samples

\begin{tabular}{|c|c|c|c|c|}
\hline \multirow{2}{*}{ Parameter } & \multicolumn{4}{|c|}{ Drying time, $\mathrm{h}$} \\
\hline & 0 & 24 & 48 & 56 \\
\hline Moisture, \% & $43.76 \pm 0.12^{\mathrm{a}}$ & $39.80 \pm 0.19^{b}$ & $31.27 \pm 0.05^{\mathrm{c}}$ & $29.11 \pm 0.13^{\mathrm{c}}$ \\
\hline Total carotene content, mg $100 \mathrm{~g}^{-1} \mathrm{DW}$ & $3.31 \pm 0.16^{\mathrm{a}}$ & $2.83 \pm 0.07^{\mathrm{b}}$ & $2.82 \pm 0.21^{\mathrm{b}}$ & $2.86 \pm 0.04^{\mathrm{b}}$ \\
\hline Ascorbic acid content, mg $100 \mathrm{~g}^{-1} \mathrm{DW}$ & $14.75 \pm 0.48^{\mathrm{a}}$ & $5.45 \pm 0.21^{\mathrm{b}}$ & $3.68 \pm 0.66^{\mathrm{c}}$ & $2.18 \pm 0.46^{\mathrm{c}}$ \\
\hline Hardness, N & $1.85 \pm 0.09^{\mathrm{d}}$ & $5.82 \pm 0.21^{\mathrm{c}}$ & $7.57 \pm 0.63^{\mathrm{b}}$ & $9.54 \pm 0.62^{\mathrm{a}}$ \\
\hline
\end{tabular}

* Values marked with the same subscript letters in rows are not significantly different $(p>0.05)$.

Pumpkin-rowanberry marmalade samples showed a significant $(p=0.000)$ loss of ascorbic acid content during drying, which was 63-85\% depending on the drying time. The results indicated vitamin $\mathrm{C}$ oxidation during marmalade treatment and drying, because the product was subjected to heat treatment in the presence of air.

The hardness of the pumpkin-rowanberry marmalades varied from 1.85 to $9.54 \mathrm{~N}$. The hardness of pumpkin-rowanberry marmalades after sample drying at $50 \pm 2{ }^{\circ} \mathrm{C}$ for 24,48 and $56 \mathrm{~h}$ increased 3,4 and 5 times, respectively. Pearson's correlation analysis was carried out to compare the quality indicators of the pumpkinrowanberry marmalades, and a negative correlation was determined between moisture and hardness $(p=0.000$, $r=-0.968)$. The hardness of marmalade samples was highly dependent on drying time, and the major reason for hardening was water vapour during drying.

The drying time of marmalade samples at $50 \pm 2{ }^{\circ} \mathrm{C}$ for 24, 48 and $56 \mathrm{~h}$ significantly $(p=0.000)$ affected also the colour of pumpkin-rowanberry marmalade. The results of colour $\mathrm{L}^{*} \mathrm{a}^{*} \mathrm{~b}^{*}$ measurements are shown in Table 2.

Table 2. The colour of pumpkin-rowanberry marmalades in CIE $L^{*} a^{*} b^{*}$ system

\begin{tabular}{|l|c|c|c|}
\hline \multirow{2}{*}{ Drying time of marmalade } & \multicolumn{3}{|c|}{ Colour values } \\
\cline { 2 - 4 } & $\mathrm{L}^{*}$ & $\mathrm{a}^{*}$ & $\mathrm{~b}^{*}$ \\
\hline 0 hours & $36.31 \pm 0.84^{\mathrm{a}}$ & $5.60 \pm 0.55^{\mathrm{b}}$ & $29.25 \pm 1.19^{\mathrm{b}}$ \\
\hline 24 hours & $36.02 \pm 0.37^{\mathrm{a}}$ & $6.60 \pm 0.32^{\mathrm{a}}$ & $33.42 \pm 1.44^{\mathrm{a}}$ \\
\hline 48 hours & $33.38 \pm 0.74^{\mathrm{b}}$ & $6.82 \pm 0.27^{\mathrm{a}}$ & $29.66 \pm 1.82^{\mathrm{b}}$ \\
\hline 56 hours & $32.66 \pm 0.54^{\mathrm{c}}$ & $6.92 \pm 0.29^{\mathrm{a}}$ & $28.00 \pm 1.92^{\mathrm{b}}$ \\
\hline
\end{tabular}

* Values marked with the same subscript letters are not significantly different ( $p>0.05$, Duncan).

The results showed that marmalade samples before drying were the lightest $\left(\mathrm{L}^{*}=36.31 \pm 0.84\right)$, and during drying at $50 \pm 2{ }^{\circ} \mathrm{C}$ they became darker, a little redder and yellowish. The darkest and the reddest colours were detected in the marmalade samples dried at $50 \pm 2{ }^{\circ} \mathrm{C}$ for 56 hours. These colour changes seem to show the emerging of brown colour, the loss of colour quality.
The results of the analysis of variance (ANOVA) indicate that $F_{c a l}=101.0>F_{c r i t}=7.81$, so there are significant differences in the degree of hardness among the pumpkin-rowanberry marmalade samples. The results of hardness evaluation scores of the marmalades are summarized in Fig. 2.

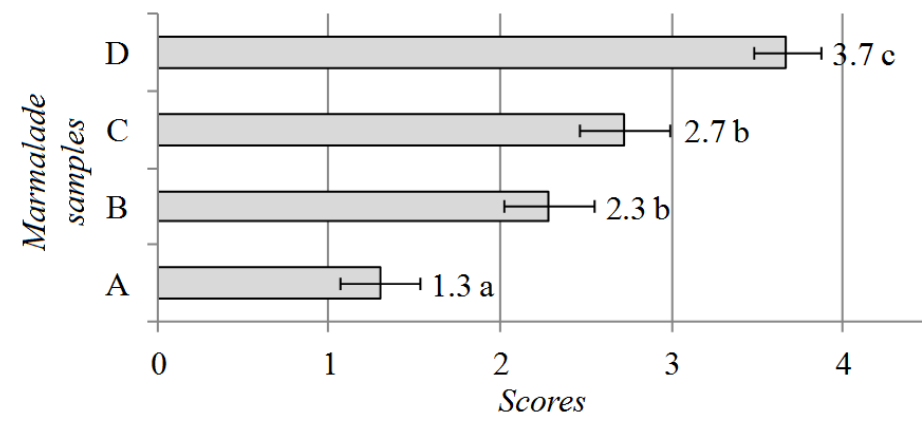

Fig. 2. The pumpkin-rowanberry marmalade hardness ranking test results

* Values marked with the same subscript letters are not significantly different $(p>0.05)$.

Drying time of pumpkin-rowanberry marmalade samples at $50 \pm 2{ }^{\circ} \mathrm{C}: \mathrm{A}-0 \mathrm{~h} ; \mathrm{B}-24 \mathrm{~h} ; \mathrm{C}-48 \mathrm{~h} ; \mathrm{D}-56 \mathrm{~h}$.

Results of the sensory evaluation of the pumpkinrowanberry marmalade hardness showed that consumers found the softest sample to be marmalade dried at room temperature, while the hardest were samples dried at $50 \pm 2{ }^{\circ} \mathrm{C}$ for 56 hours (see Fig. 1). Among marmalade samples dried at $50 \pm 2{ }^{\circ} \mathrm{C}$ for 24 and 48 hours, there were no significant differences $(p>0.05)$.

The summary of consumers' questionnaires showed that the majority (i. e. $54 \%$ of the respondents) preferred the softest pumpkin-rowanberry marmalade (i. e. samples 
dried at room temperature), while some consumers (17\% of the respondents) liked the marmalade which was the hardest (see Fig. 3). Marmalades of a medium hardness (dried at $50 \pm 2{ }^{\circ} \mathrm{C}$ for 48 hours) had the lowest acceptability.

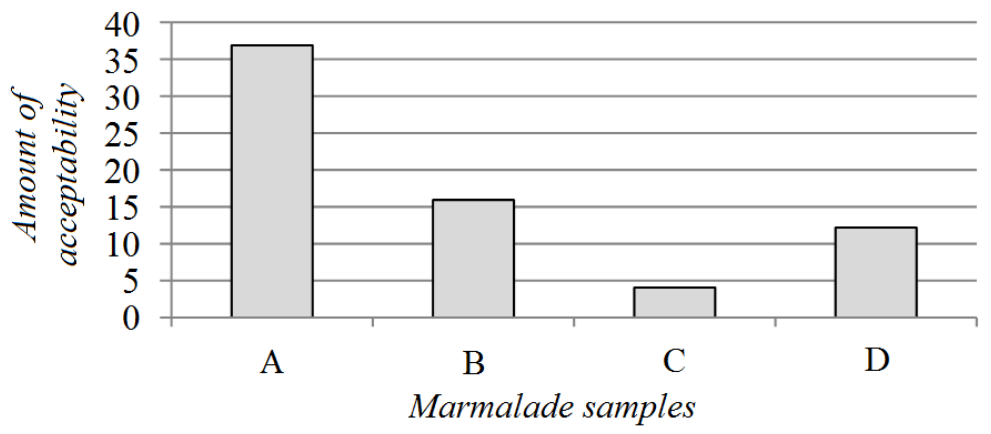

Fig. 3. The ranking of test results of pumpkin-rowanberry marmalade hardness

Drying time of pumpkin-rowanberry marmalade samples at $50 \pm 2{ }^{\circ} \mathrm{C}: \mathrm{A}-0 \mathrm{~h} ; \mathrm{B}-24 \mathrm{~h} ; \mathrm{C}-48 \mathrm{~h} ; \mathrm{D}-56 \mathrm{~h}$.

The majority of consumers considered the marmalades dried at room temperature $\left(22 \pm 2{ }^{\circ} \mathrm{C}\right)$ to be suitable for the preparation of pumpkin-rowanberry marmalade because of their softer texture.

\section{Conclusions}

1. The results of the research show a large variability $(p=0.000)$ of the physical and chemical parameters among pumpkin-rowanberry marmalades dried for different times. The moisture content varied from 29.11 to $49.60 \%$ and hardness from 1.85 to $9.54 \mathrm{~N}$.

2. The highest content of carotenes $\left(3.31 \mathrm{mg} 100 \mathrm{~g}^{-1}\right.$ DW) and ascorbic acid (14.75 $\pm 0.48 \mathrm{mg} 100 \mathrm{~g}^{-1}$ DW) was detected in the marmalade dried at room temperature.

3. Consumers preferred the marmalade sample with the softest texture. Therefore, drying the product for 24 hours at room temperature could be recommended as the best way of the production of soft marmalades.

\section{Acknowledgements}

The research and publication have been prepared within the framework of the ESF Project No. 2011/0055/1DP/1.1.2.1.2/11/IPIA/VIAA/008, Contract No. 04.4-08/EF10.PD.03.

\section{References}

1. Sikorski Z. E. Chemical and Functional Properties of Food Components. 2007. Boca Raton: CRC Press; Taylor \& Francis Group, P. 427-437.

2. Figuerola F.E. Berry fruit: value-added products for health promotion. 2007. Boca Raton: CRC Press, P. 367386.

http://dx.doi.org/10.1201/9781420006148.ch13

3. Grujić S., Grujić R., Poljašević J. // Electronic Journal of Polish Agricultural Universities (EJPAU), 2010. Vol. 13 (2), \#11, P. 1-12.
4. Willats W. G. T., Knox J. P., Mikkelsen J. D. // Trends in Food Science \& Technology. 2006, Vol. 17. P. 97-104. http://dx.doi.org/10.1016/j.tifs.2005.10.008

5. Fügel R., Carle R., Schieber A. // Trends in Food Science \& Technology. 2005. Vol. 16. P. 433-441. http://dx.doi.org/10.1016/j.tifs.2005.07.001

6. Lee C. H., Cho J. K., Lee S. J., Koh W., Park W., Kim C. H. // Cereal Chemistry. 2002. Vol. 79. N 4. P. 593595. http://dx.doi.org/10.1094/CCHEM.2002.79.4.593

7. Gajewski M., Radzanowska J., Danilcenko H., Jariene E., Cerniauskiene J. // Notulae Botanicae Horti Agrobotanici Cluj-Napoca. 2008. Vol. 36. N 1. P. 73-79.

8. See E. F., Wan Nadiah W. A., Noor Aziah A. A. // ASEAN Food Journal. 2007. Vol. 14. N 2. P. 123-130.

9. Bushway R. J. // Journal of Agricultural and Food Chemistry. 1986. Vol. 34. P. 409-412. http://dx.doi.org/10.1021/jf00069a006

10. Noelia J., Roberto M. M., de Jesus Z. J., Alberto G. J. // Notulae Botanicae Horti Agrobotanici Cluj-Napoca. 2011. Vol. 39. N 1. P. 34-40.

11. Figueredo E., Minguez A., Luis Vidarte L. // Journal of Allergy Clinical Immunology. 2000. Vol. 106. P. 402403.

http://dx.doi.org/10.1067/mai.2000.108109

12. Hukkanen A. T., Polonen S. S., Karenlampi S. O., Kokko H. I. // Journal of agricultural and food chemistry. 2006. Vol. 54. N 1. P. 112-119. http://dx.doi.org/10.1021/jf051697g

13. Poyrazoğlu E. S. // Journal of Food Quality. 2004. Vol. 27. P. 366-370. http://dx.doi.org/10.1111/j.1745-4557.2004.00658.x

14. Souci S. W., Fachmann W., Kraut H. Food composition and nutrition tables = Die Zusammensetzung der Lebensmittel, Nährwert-Tabellen, 7th edition, 2008. Germany: Medpharm Scientific Publishers. P. 1087.

15. Navys E. // Acta Biologica Universitatis Daugavpiliensis. 2001. Vol. 1 (2). P. 94-98.

16. Tomás-Barberán F. A, Gil M. I. Improving the healthpromoting properties of fruit and vegetable products. 2008. UK: Woodhead Publishing Limited. P. 449-472.

17. Ratti C. // Journal of Food Engineering. 2001. Vol. 49. P. 311-319. http://dx.doi.org/10.1016/S0260-8774(00)00228-4

18. Heldman D. R., Lund D. B. Handbook of Food Engineering.2nd ed. 2007. CRC Press Taylor \& Francis Group. P. 1038. 
19. Rózek A., García-Pérez J. V., López F., Güell C., Ferrando M. // Journal of Food Engineering. 2010. Vol. 99. P. 142-150. http://dx.doi.org/10.1016/j.jfoodeng.2010.02.011

20. Stojanovic J., Silva J. L. // Food Chemistry. 2007. Vol. 101. P. 898-906. http://dx.doi.org/10.1016/j.foodchem.2006.02.044

21. Kopjar M., Piližota V., Tiban N. N., Šubarić D., Babić J., Ačkar Đ., Sajdl M. // Czech Journal of Food Sciences. 2009. Vol. 27. P. 20-28.

22. García-Viguera C., Zafrilla P., Artés F., Romero F., Abellán P., Tomás-Barberán F. A. // Journal of the Science of Food and Agriculture. 1998. Vol. 78. N 4. P. 565-573. http://dx.doi.org/10.1002/(SICI)10970010(199812)78:4<565::AID-JSFA154>3.0.CO;2-P

23. Mattila P., Hellström J., Törrönen R. // Journal of agricultural and food chemistry. 2006. Vol. 54. N 19. P. 7193-7199. http://dx.doi.org/10.1021/jf0615247

24. Ермаков А. Методы биохимического исследования растений. 1987. Ленинград: Агропромиздат, с. 112 113.

25. Muizniece-Brasava S., Dukalska L., Kampuse S., Murniece I., Sabovics M., Dabina-Bicka I., Kozlinskis E., Sarvi S. // World Academy of Science, Engineering and Technology. 2011. Issue 56. Vol. 80. P. 555-563.

26. Coultate T. P. Food: the chemistry of its components, 4 th edition, 2002. UK: Cambridge. P. 213-217.

27. Chakrborty R., Bera M., Mukhopadhyay P., Bhattacharya P. // Separation and Purification Technology. 2011. Vol. 80. P. 375-384. http://dx.doi.org/10.1016/j.seppur.2011.05.023
E. Berna, S. Kampuse, M. Sabovics, E. Straumite

\section{IVAIRIAI DŽIOVINTO MOLIŪGŲ IR ŠERMUKŠNIŲ MARMELADO KOKYBĖS VERTINIMAS}

\section{S a n t r a u a}

Istoriškai marmeladai gaminami norint išsaugoti vaisius ir juos vartoti ne sezono metu. Marmeladai iš esmès yra vaisių tyrès ir cukraus, rūgšties ir pektino gelio produktas. Šio darbo tikslas - nustatyti įvairiai džiovinto moliūgų ir šermukšnių marmelado chemines ir fizikines savybes bei priimtinumą vartotojams.

Eksperimentai buvo atlikti Latvijos Žemès ūkio universiteto Maisto technologijos fakultete. Marmeladas pagamintas iš moliūgų Cucurbita maxima ir šermukšnių Sorbus aucuparia atmainos „Nevezhinskaya“ saldžios tyrès. Skirtingą laiką $50 \pm 2{ }^{\circ} \mathrm{C}$ temperatūroje džiovinto marmelado savybès buvo lygintos su marmelado, džiovinto kambario temperatūroje, savybèmis. Marmelado mèginių kokybè vertinta nustačius drègmès, bendro karotino, askorbo rūgšties kiekį, kietumą, spalvą ir priimtinumą vartotojams.

Tyrimų rezultatai parodè, kad skirtingą laiką džiovinto marmelado fizikiniai ir cheminiai parametru labai svyruoja. Marmelado mėginių drègmès kiekis sumažèjo nuo 9,1 iki $33,5 \%$, o kietumas padidejo nuo 1,85 iki 9,54 N. Kambario temperatūroje džiovintas moliūgų ir šermukšnių marmeladas buvo priimtiniausias vartotojams. 